\title{
Anaplastic Large Cell Lymphoma, Signet Ring-Like Subtype
}

National Cancer Institute

\section{Source}

National Cancer Institute. Anaplastic Large Cell Lymphoma, Signet Ring-Like Subtype. NCI Thesaurus. Code C39676.

An anaplastic large cell lymphoma, characterized by lymphoid cells with signet ring nuclei. 